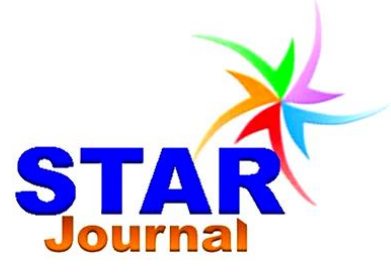

ISSN: 2226-7522(Print) and 2305-3327 (Online) Science, Technology and Arts Research Journal

July-Sep 2013, 2(3): 114-125

www.starjournal.org

Copyright@2013 STAR Journal. All Rights Reserved

Original Research

\title{
Identification of Groundwater Level by Using Geoelectrical Resistivity Method at Fincha'a Sugar Estate, Blue Nile Basin, Western Ethiopia
}

\author{
Getahun Kitila $^{1 *}$, Geremew Lemessa ${ }^{1}$, Heluf Gebrekidan ${ }^{2}$ and Tena Alamirew ${ }^{2}$ \\ ${ }^{1}$ College of Natural and Computational Sciences, Wollega University, Post Box No: 395, Nekemte, Ethiopia \\ ${ }^{2}$ School of Natural Resource Management and Environmental Science, Haramaya University, \\ Post Box No: 138, Dire Dawa, Ethiopia
}

\begin{tabular}{|c|c|}
\hline $\begin{array}{l}\text { Abstract } \\
\text { Good water management and improved drainage can minimize yield reductions } \\
\text { caused by waterlogging and thus increase profitability. Waterlogging became a very } \\
\text { severe problem in some of the irrigated fields of Fincha'a Sugar Estate in the Blue Nile } \\
\text { Basin of western Ethiopia. As a result many productive agricultural lands were } \\
\text { abandoned. A measurement of geoelectrical resistivity at the selected irrigated fields } \\
\text { by using Schlumberger array with the space of potential and current electrode was } \\
\text { found to be } 2 \mathrm{~m} \text {. The positions of centre sounding measurements to be investigated } \\
\text { were at different points along the traverse line (subsurface area). The objective of this } \\
\text { study was to identify the depth of the groundwater table in relation to aquifers and } \\
\text { subsurface lithology. The shallow ground water was identified at the depth of } 1.5,2.06 \text {, } \\
3.18 \text { and } 2.49 \mathrm{~m} \text { with resistivity values of } 3.76,5.42,49.3 \text {, and } 29.4 \Omega \text {-m at (VES } 1 \text { ), } \\
\text { (VES } 2 \text { ), (VES } 3 \text { ) and (VES } 4 \text { ) respectively. While the deep ground water table } \\
\text { confined on the course range from the depth of } 3.96 \text { to } 11.6 \text { m with the resistivity value } \\
\text { of } 3.96 \text { to } 11.6 \Omega \text {-m. The variation of resistivity values from each position of ground } \\
\text { water shows the variation of variation of crack dimension and variation of medium type. } \\
\text { It was identified that the selected irrigated fields are under severe to critically } \\
\text { waterlogged conditions. Deeper regolith (3.18-20.7) m was resistive, both above and } \\
\text { below the water table, due to low salinities in the groundwater and coarser textures. }\end{array}$ & Intormatic \\
\hline \multirow{10}{*}{$\begin{array}{l}\text { Good water management and improved drainage can minimize yield reductions } \\
\text { caused by waterlogging and thus increase profitability. Waterlogging became a very } \\
\text { severe problem in some of the irrigated fields of Fincha'a Sugar Estate in the Blue Nile } \\
\text { Basin of western Ethiopia. As a result many productive agricultural lands were } \\
\text { abandoned. A measurement of geoelectrical resistivity at the selected irrigated fields } \\
\text { by using Schlumberger array with the space of potential and current electrode was } \\
\text { found to be } 2 \mathrm{~m} \text {. The positions of centre sounding measurements to be investigated } \\
\text { were at different points along the traverse line (subsurface area). The objective of this } \\
\text { study was to identify the depth of the groundwater table in relation to aquifers and } \\
\text { subsurface lithology. The shallow ground water was identified at the depth of } 1.5,2.06 \text {, } \\
3.18 \text { and } 2.49 \text { m with resistivity values of } 3.76,5.42,49.3 \text {, and } 29.4 \Omega-m \text { at (VES } 1) \text {, } \\
\text { (VES 2), (VES } 3 \text { ) and (VES 4) respectively. While the deep ground water table } \\
\text { confined on the course range from the depth of } 3.96 \text { to } 11.6 \text { m with the resistivity value } \\
\text { of } 3.96 \text { to } 11.6 \Omega \text {-m. The variation of resistivity values from each position of ground } \\
\text { water shows the variation of variation of crack dimension and variation of medium type. } \\
\text { It was identified that the selected irrigated fields are under severe to critically } \\
\text { waterlogged conditions. Deeper regolith (3.18-20.7) m was resistive, both above and } \\
\text { below the water table due tolow salinities in the groundwater and coarser textures }\end{array}$} & \\
\hline & sed \\
\hline & ted \\
\hline & \\
\hline & level \\
\hline & le \\
\hline & \\
\hline & \\
\hline & \\
\hline & \\
\hline
\end{tabular}

\section{INTRODUCTION}

Irrigation alters the surface water balance. Water not used for plant growth or lost to evaporation, drains below the root zone (Jenny et al., 2010). There is some evidence, from bore monitoring, of rises in groundwater level in shallower aquifers in the alluvium (DERM groundwater database), likely due to recharge from deep drainage (Murphy, 2008), but many shallower bores have been dry for many years. Diffuse recharge (i.e. through the soil) in the alluvium is considered to be small, with the aquifers mainly recharged by river leakage (Gunawardena et al., 2008). Thus there is a disparity deep drainage below the root zone is seen to be high but recharge from this source is thought to be low. This would be explained, in part, if deep drainage was being stored in an unsaturated zone left dry by the previous native vegetation, creating a time lag between deep drainage and recharge. Little is known about the moisture capacity and status of the regolith (unsaturated zone) or how this has changed as a result of changes in the soil water balance. Soil resistivity is related to soil water content, salinity and clay (content and type). Data can be interpreted qualitatively with the aid of lithology from bore logs and measures of salt and clay content. Contrasts in regolith under native vegetation and under irrigated agriculture were examined, to assess the impacts from land use changes (Jenny et al., 2010).

Geophysical techniques are the highly useful for the identification of groundwater potential zones and groundwater level studies, to investigate the nature and status of subsurface 
Getahun Kitila et al.,

saline water contamination. Among various geophysical studies, the Schlumberger configuration was used in determination of depth, thickness and boundary of an aquifer (Omosuyi et al., 2007; Ismail Mohameden, 2005 and Olowofela et al., 2005 and Oseji et al., 2005) and exploration of geothermal reservoirs (El-Qady, 2006) and estimation of hydraulic conductivity of aquifer (Khalil and Monterio, 2009). Vertical Electrical Sounding method was chosen because, the instrumentation is simple, field logistics are easy and straight forward while the analysis of data is less tedious and economical (Selvam and Sivasubramanian, 2012). Using this method, depth and thickness of various subsurface layers and their water yielding capabilities can be inferred. Aquifer resistivity is controlled by water content, water quality and grain matrix (Tahmasbinejad, 2009; Yusuf et al., 2011). When the distance between the current electrodes is increased the depth to which the current penetrates is increased (Bobachev and Igor, 2000, Amadi et al., 2011). The current electrodes spacing $(A B)$ increases after each reading while the potential electrodes spacing ( $\mathrm{MN}$ ) increases only when deemed necessary and controlled by the relation $A B / 2 \geq 5 M N / 2$ as required by the Schlumberger array (Patra et al., 1999).

The waterlogging in some sugar plantation irrigation fields of Fincha'a sugar estate have an effect on yield of sugar cane and the productivity of the estate. To ensure its negative impact, a combined hydrological and hydrogeological study was needed in place. The main objective of the present study was to identify the groundwater level condition and the nature of subsurface layers within the selected waterlogged irrigated fields of Fincha'a sugar estate. Vertical Electrical Sounding (VES) was used to carry out groundwater level identification in the present study area. The results of the study could be used to locate the positions and dimensions of the drainage ditch in order to carbe the existing waterlogging problems and increase the productivity of the Sugar cane.

\section{MATERIALS AND METHODS}

\section{Geographical Environment}

The study was conducted in FSE in the Fincha'a valley, Abay cowman district, Horo Guduru zone (HGZ), Oromia Regional State (ORS), Blue Nile basin (BNB), Ethiopia (Figure 1) lying between $9^{\circ} 30^{\prime}$ to $10^{\circ} 00^{\prime} \mathrm{N}$ latitude and $37^{\circ} 15^{\prime}$ to $37^{\circ} 30^{\prime} \mathrm{E}$ longitude a distance of $340 \mathrm{~km}$ from Addis Ababa, the capital of Ethiopia with altitude variation from1350 to $1600 \mathrm{~m}$ above sea level and bounded by the Amhara National Regional state in the North, Guduru Woreda in the East, Horro Woreda in the West and Jarte and Amuru Woreda in the South
Sci. Technol. Arts Res. J., July-Sep 2013, 2(3): 114-125

respectively. The total command area of the valley is 65,000 ha. The thirty years (1979-2012) climatic data from FSE Meteorological Station recorded the yearly average annual rainfall $1315.5 \mathrm{~mm}$ which is characterized by unimodal rainfall pattern. About 80 $\%$ of the annual rain falls between May to September its mean annual maximum and minimum temperatures lies between 30.5 and $14.85^{\circ} \mathrm{C}$ (Figure 3) Average pan evaporation was $153.1 \mathrm{~mm}$ and the average annual reference evapotranspiration (based on Penman-Monteith) is 1320 $\mathrm{mm}$, with monthly low variation (Ambachew and Girma, 2005). The average annual relative humidity is about $83.8 \%$ (Baissa, 2007). Fincha'a valley has alternate wet (during May to October) and dry (during the rest of the months) seasons Wind speed in Fincha'a Valley is low as the surrounding escarpments hinder wind movement. However, wind speed is high between the months of March to June (Worku, 1995, Ademe, 2001).The study area falls in the humid agro-climatic zonation (MOA, 1998) on the basis of altitudinal and annual rainfall variations.

According to the extracted BNB digital soil (1974) data obtained from Ministry of Water and Energy of Ethiopia (MWEE, 2011), the soil classes of the study area are Cambisols, Luvisols, Leptosols, Alisols, Marsh, Vertisols and water associated with the geomorphology and the geology of the area (Figure 4) and topographically surrounded by escarpments and steep side sloping landscape. The steep side slopes and escarpments of mountain plateau and gorges have very shallow soils. (Dereje, 1995) reported that Luvisols are relatively good in drainage and mineral composition and are largely $(75 \%)$ distributed and the Vertisols are characterized with poor drainage and high water holding capacity and the distribution is $(23 \%)$. Most of the Luvisols are situated in the middle of the interfluves. Nineteen percent of the Luvisols are moderately deep. Vertisols are found mostly in the lower areas near The Agul River and at the upper ends of the interfluves (Worku, 1995). Sugarcane mono cropping based on irrigation agriculture is the main agricultural activity taking over. The area is mainly drained by the Fincha'a river. Fincha'a Valley has quite diversified physical landscape with Topography ranging from 892 to 2520 (Figure 2). Slope for the study varies from, flat $(0-2 \%)$, moderately steep (16-30\%), Gently Undulating (2-8 $\%)$, Rolling (8 - 16\%) and to steep (> $30 \%)$, (Figure $5)$. Geologically, the Adigrat sandstone formation, which is composed of alternating beds of sandstones and shales and have been deposited unconformable upon the eroded surfaces of the Basement Complex is commonly is commonly distributed. The study area is surrounded by 


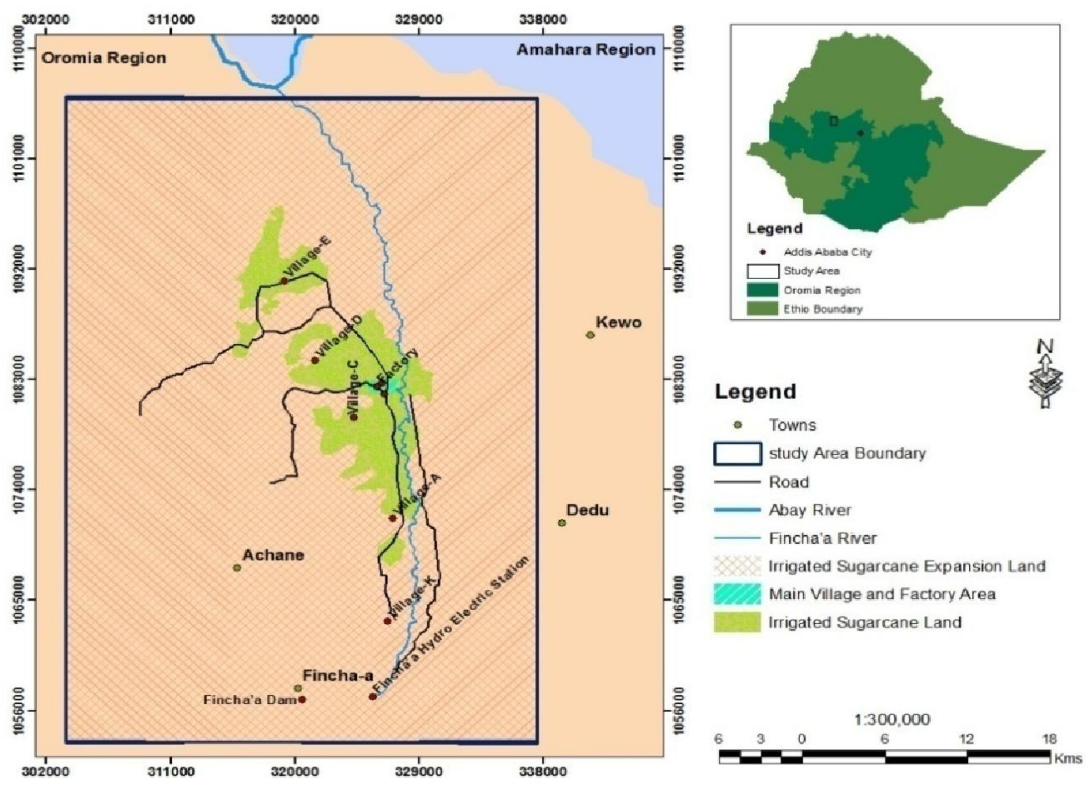

Figure 1: Location map of the study area.

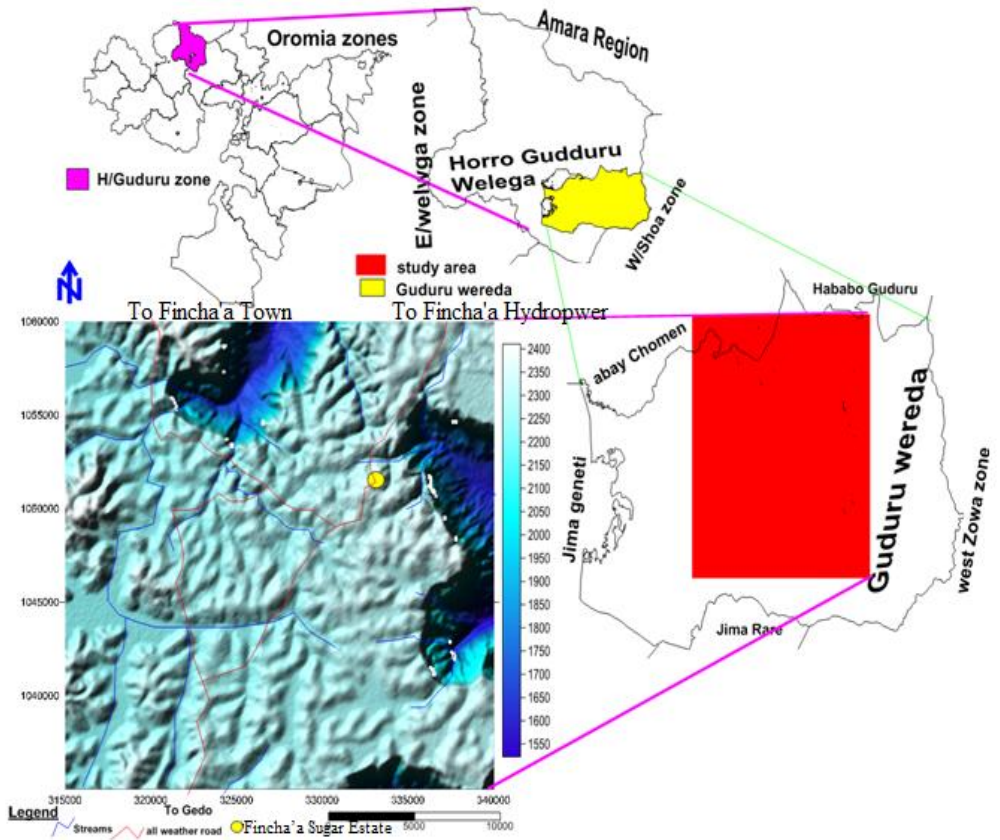

Figure 2: accessibility, drainage and location map of study Area.

escarpment along its southern, eastern and western sides, which rise approximately $700-850 \mathrm{~m}$ above the valley floor. The floor of the valley is dominated by a gently undulating slope (1- $8 \%$ ) surface northwards Ahmed (2007). The width of the valley, generally, increases from south to north with an average size ranging from 25 to $30 \mathrm{~km}$.

\section{Methodology}

Electrical prospecting makes use of a variety of principles, each based on some electrical properties or characteristics of the materials within the earth (Singh et.al., 2002). In this study, Vertical Electrical Sounding (VES) method has been applied. VES survey was carried out in 4 locations (Figure 2) using Schulumberger electrode configuration. The Schlumberger method was adopted for this study because of the fieldwork is faster, easier and economically save the money and software's are readily available for its interpretation (Todd 1980, Fetter 1994, Patra and Nath 1999). The resistivity values of the layers were measured using the Syscal Junior Resistivity meter model). For Schlumberger 
Getahun Kitila et al.,

soundings (Figure 6), soundings were carried with maximum current electrode spacing (AB) $1500 \mathrm{~m}$ $(A B / 2=750 \mathrm{~m})$. The distance used for potential electrode spacing (MN) ranged from $0.3 \mathrm{~m}$ to $10 \mathrm{~m}$ $(\mathrm{MN} / 2=0.15 \mathrm{~m}$ to $5 \mathrm{~m})$. At each VES station electrodes were placed in a straight line and the inter-electrode spreads were gradually increased about a fixed center. The current was sent into the ground and the potential difference $(\mathbf{V})$ due to this current was measured and recorded against the electrode spacing. With these values of currents (I) and potential (V) of the electrode configuration adopted one can get the apparent resistivities ( $\rho$ a).
Sci. Technol. Arts Res. J., July-Sep 2013, 2(3): 114-125

The apparent resistivity values were plotted against $A B / 2$ on double - log graph sheets. The manner in which apparent resistivity values increase or decrease with electrode separation forms the basis for choosing the shape of the field curve that can perform quantitative interpretation of the sub surface resistivity distribution (Singh et al., 2002). IPI2WIN software and inversion technique were implemented for data interpretation. Aerial photographs and topographic maps at a scale of 1:50,000) were used to identify the geological structures and trace them on to the topographic sheet of 1:50,000 scale. The topographic sheet

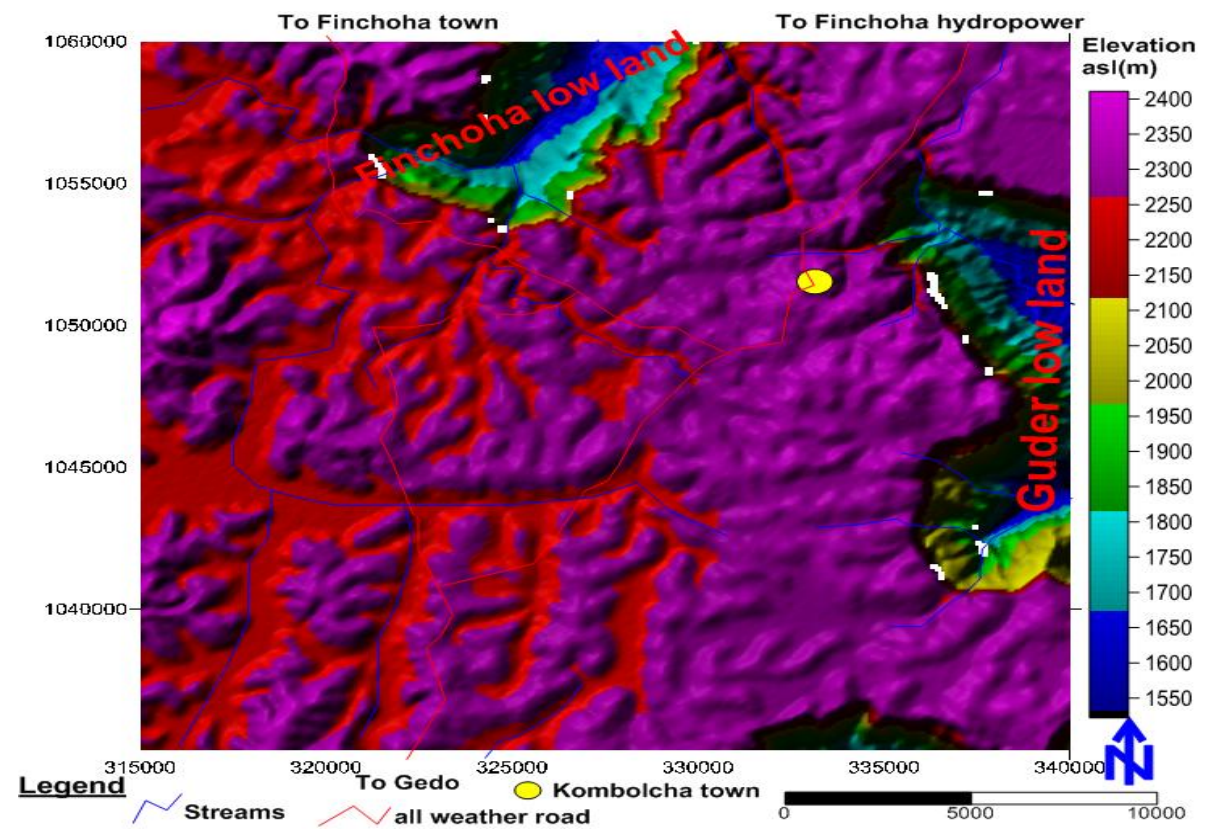

Figure 3: Physiography and drainage system of Fincha'a Sugar Estae.

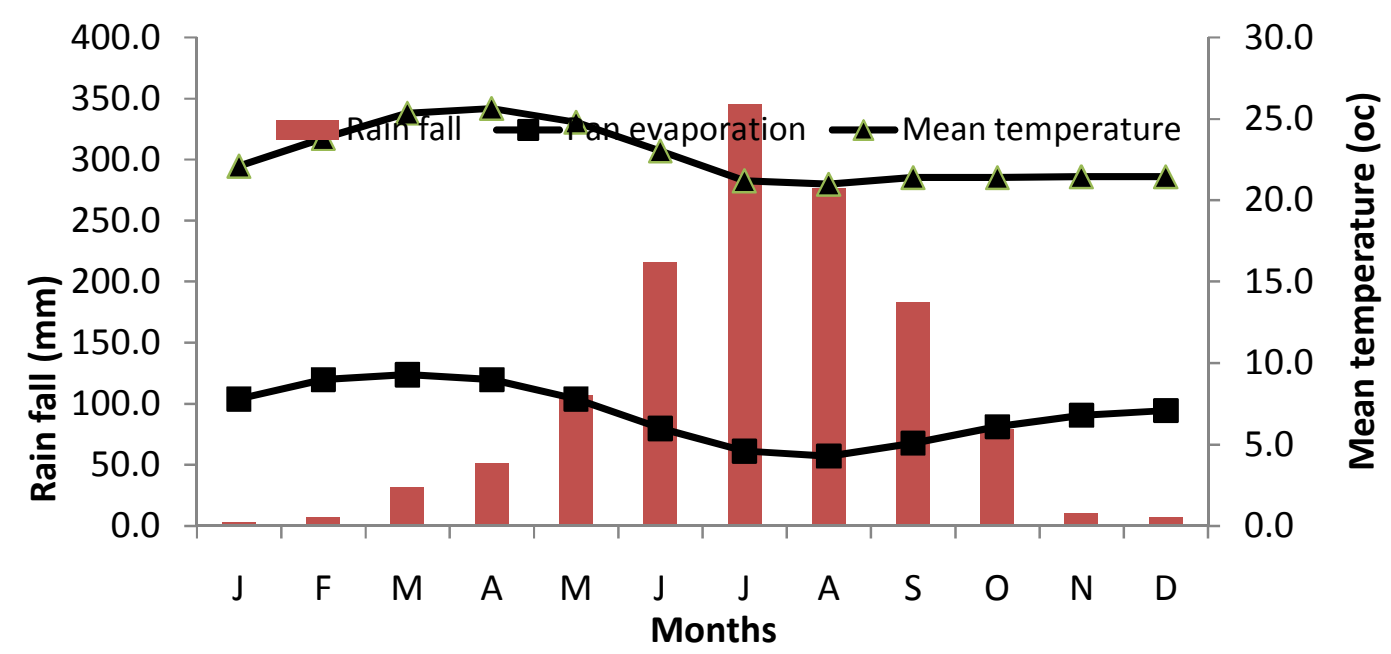

Figure 4: Mean monthly rain fall (RF), mean maximum and minimum temperatures (Temp.) and pan evaporation of the Fincha'a Sugar Estate, Blue Nile Basin, western Ethiopia based on records at the Fincha'a Sugar Estate research station methodological station (1979-2012). 


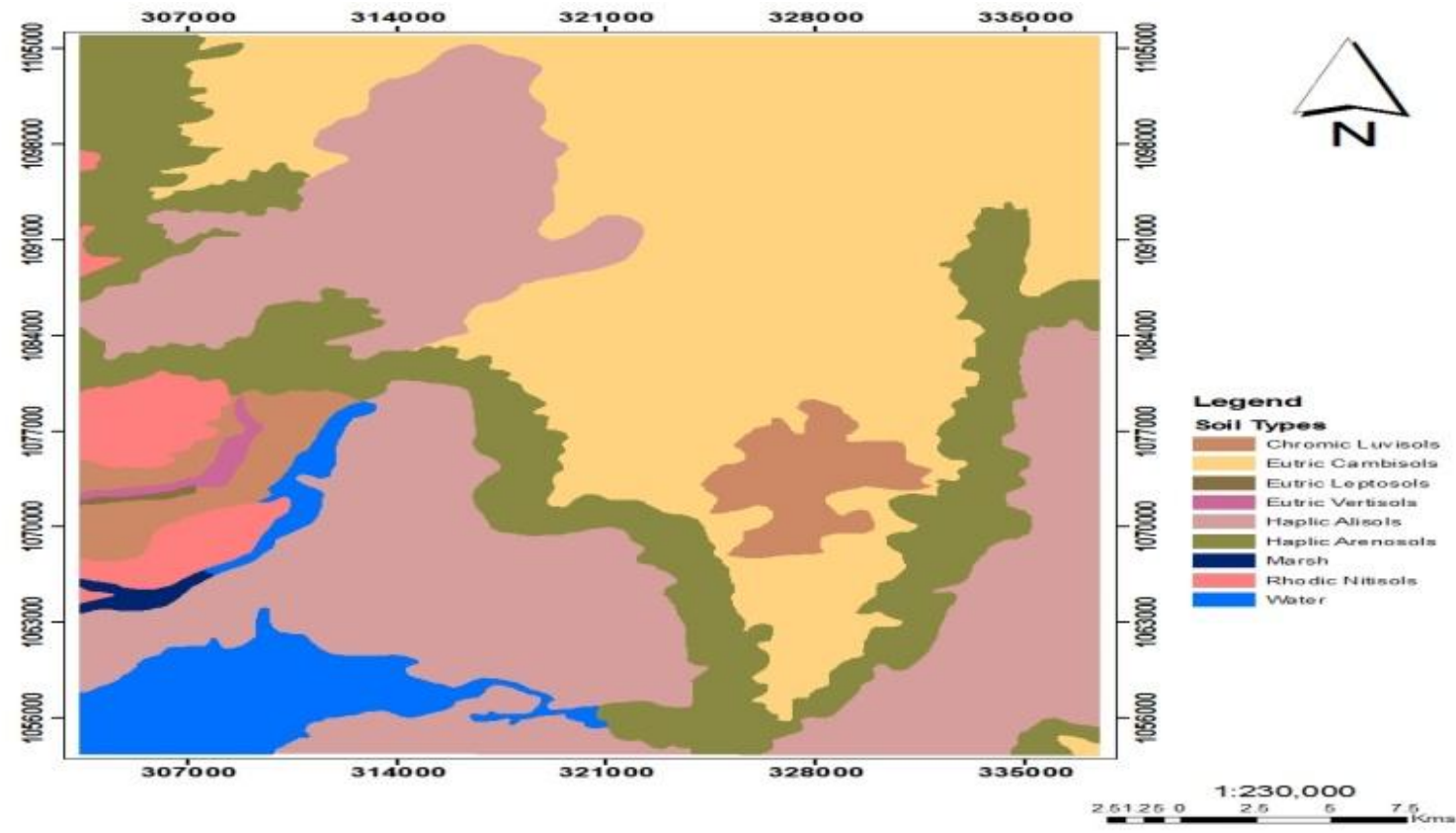

Figure 5: Soil map of Fincha'a watershed: modified from Soil Map of East Africa (1997).
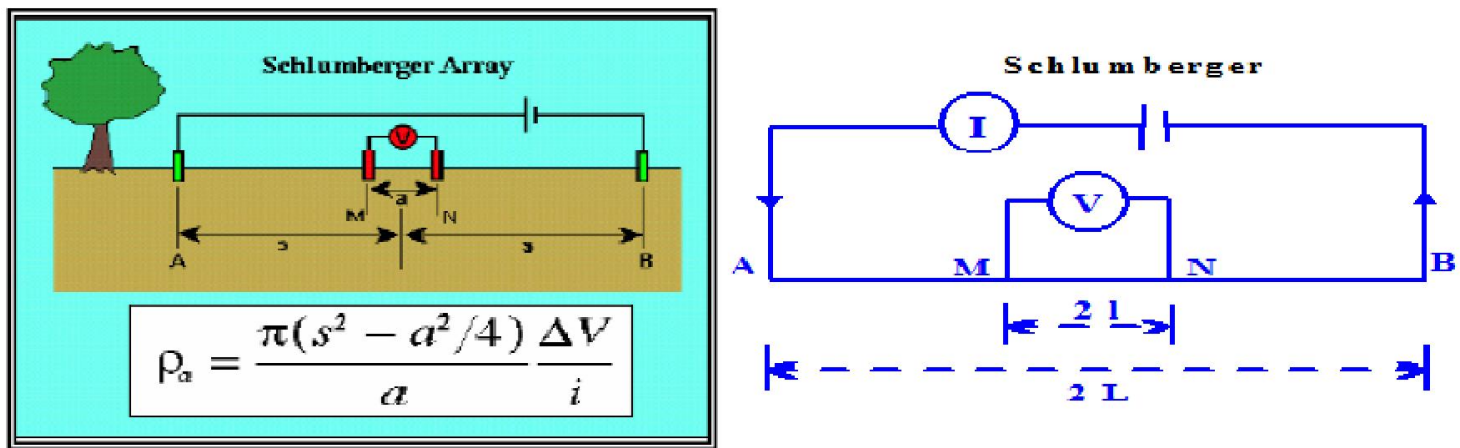

Figure 6: VES geoelectric sounding and Schlumberger array.

was used as base map in the field to mark the lithologies, their contacts and trends and to develop detailed geological and hydrogeological maps of the area. Primary geological and hydrogeological data were collected in the field after having the secondary data. Aquifers in the area of investigation were classified based on two factors: qualitative and quantitative classifications.

\section{Data Interpretations}

An iteration software (WIN RESIST) was used to iterate curves of VES. The smooth curves taken through the set of data points were interpreted quantitatively by the method of partial curve matching. Layer resistivity and thickness were got from VES1 to VES4 diagram.These curves were interpreted using the partial curve matching technique (Orellana and Mooney, 1966) and corresponding auxiliary curves to obtain the resistivity, thickness and depth of water table of each of the layers delineated. The quasi-computed resistivity values were then analyzed by the application of IPI2Win Program for inverting the $1 \mathrm{D}$ dimension. This inversion results in a $1 \mathrm{D}$ curve showing the distribution of underground electrical resistivity values. The VES was conducted in the Southwestern Eastern direction for VES1 at GPs Location of 37P, $0325839 \mathrm{mE}$, UTM, $10^{\circ} 71736 \mathrm{mN}$ an elevation of $1586 \mathrm{~m}$. a.s.I. East direction for VES 2 at GPs Location of 37P, $0325318 \mathrm{mE}$, UTM, $10^{\circ}$ $74134 \mathrm{mN}$ and elevation 1560 m.a.s.I. East-North direction for VES 3 at GPS Location of $37 p$, $0325355 \mathrm{mE}$ UTM, $10^{0}, 78960$ and elevation 1515 m.a.s.I. for VES 4 at GPs Location of 37P, $0321457 \mathrm{mE}$ UTM, $10^{\circ} 84325$ an elevation of 1506 m.a.s.l. Figure 7. 


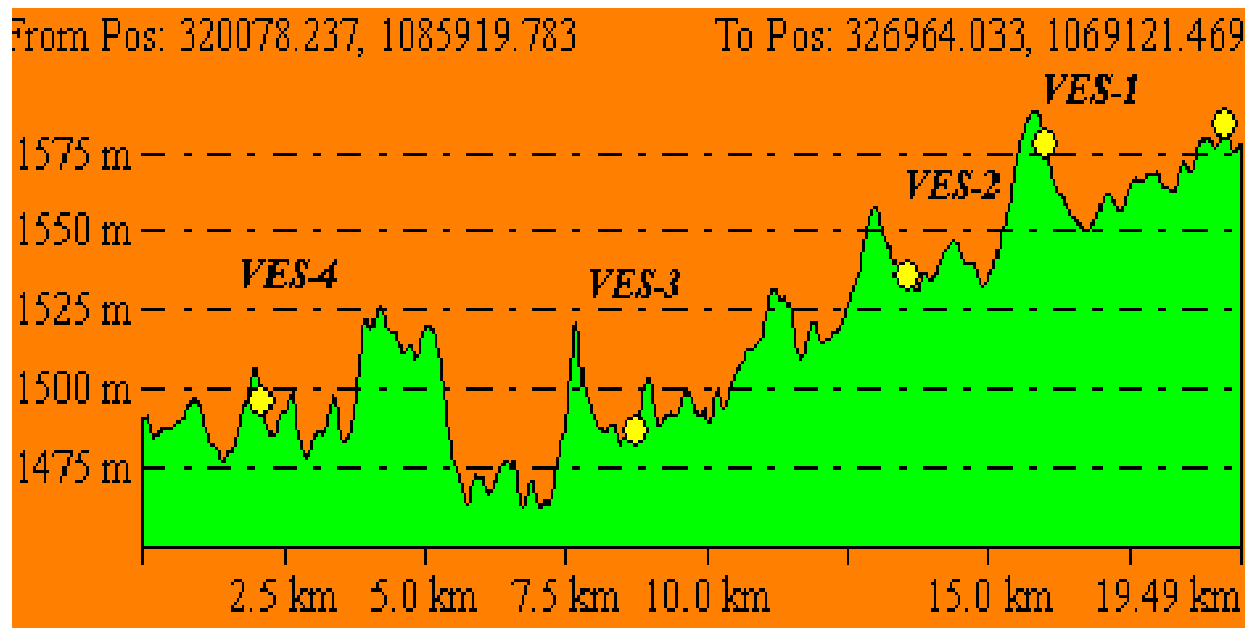

Figure 7: Location of Vertical Electrical Soundings for selected irrigation fields of FES

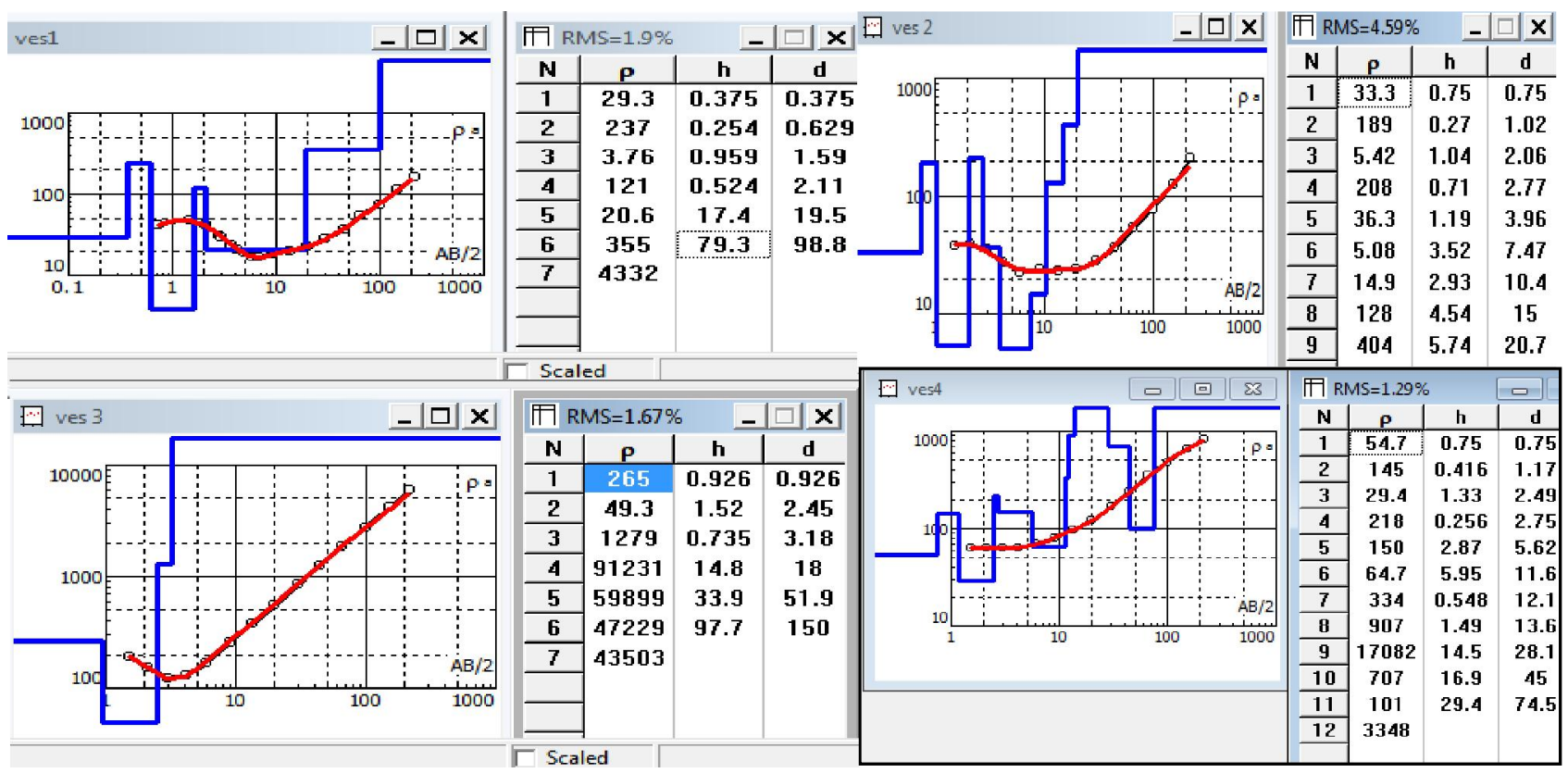

Figure 8: Interpretations of Vertical Electrical Sounding Field Curves.

\section{RESULTS}

\section{Morphology \& Soils of Selected Irrigation Site}

The topography of the site is dominated by the flat to moderately steep landscape and areas of $(0-$ $30 \%$. This site is basically part of the low land with the altitude of $28-2828 \mathrm{~m}$. The most dominant soil types in the study site are Luvisols and Vertisols. These together with topography, nature of basement rock are an indication for the selected fields to be waterlogged.

\section{Geology of the selected Irrigation site}

In terms of its geological characteristics, the site's natural condition and distribution of aquifer, aquiclud and aquitard are mainly dominated by rocks, layers and structures of geological content and formation (Ibrahim, 2008). The lithological component shows the physical structure and geological content. They consist of mineral compositions, and grain packing formed from sedimentation. Stratigraphic structure explains the age of layers, their kinds and formation. Cleavages, fractures, folds and faults show the geometric characteristics of a geological system resulting from deformation, deposition and crystallization of the rocks. For unconsolidated deposits, the lithological and stratigrafic processes play an important role to maintain a balanced structure. Plateau basalt and Adigrat sand stone were identified as highly dominant geological formations (Figure 10) with highly weathered and fractured trachyte at quarry site and recent deposit (Figure 11), alluvial deposit (Figure 12) and highly weathered and fractured basalt at local faulting (Figure 13). These are indicators of the groundwater potential of the site. 


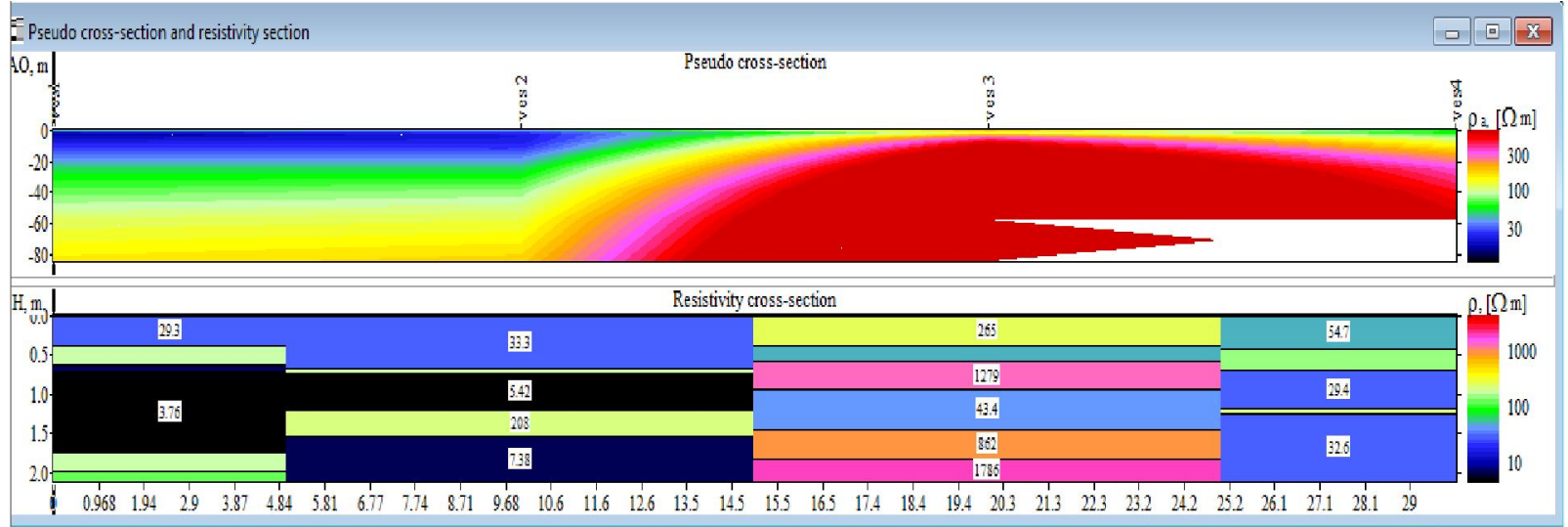

Figure 9: Pseudo cross -section and resistivity section of the study area.

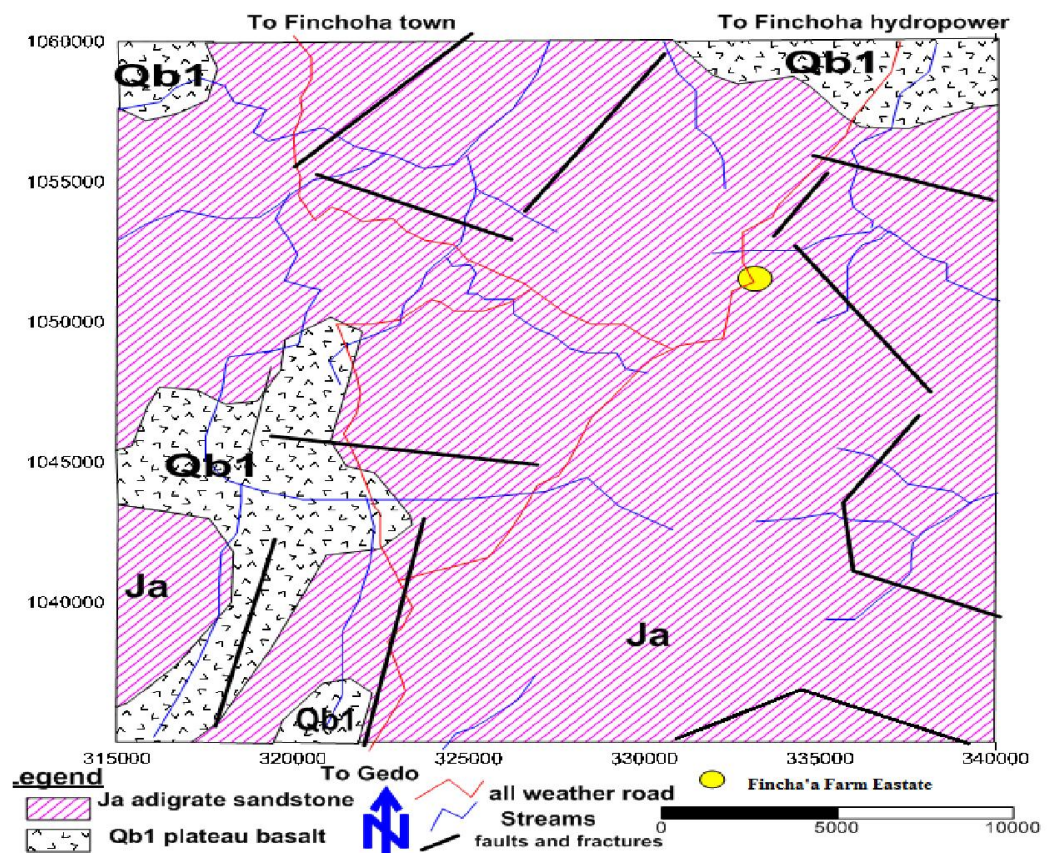

Figure 10: Geological map of Study area, (modified from geologic map of Ethiopia ,1996)

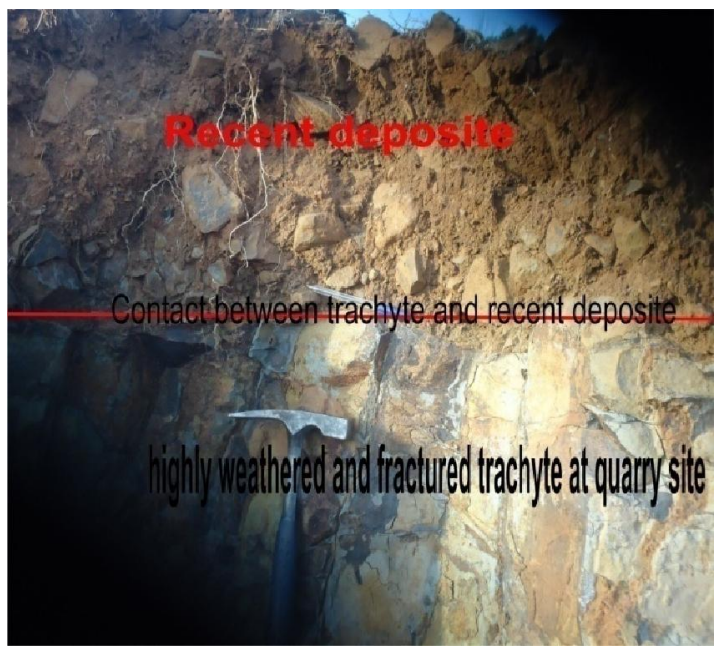

Figure 11: Highly weathered and fractured trachyte at south and west of the study (quarry site).

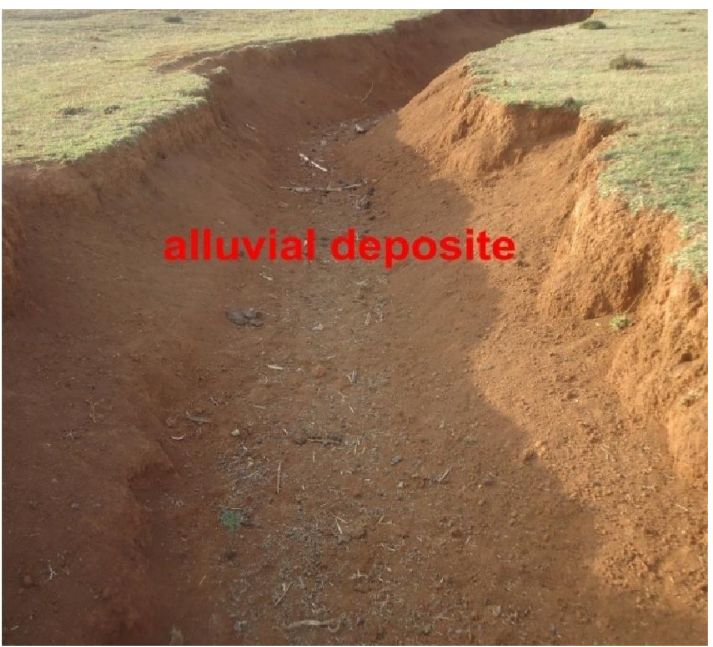

Figure 12: Alluvial deposits of the selected irrigation fields in the study area. 


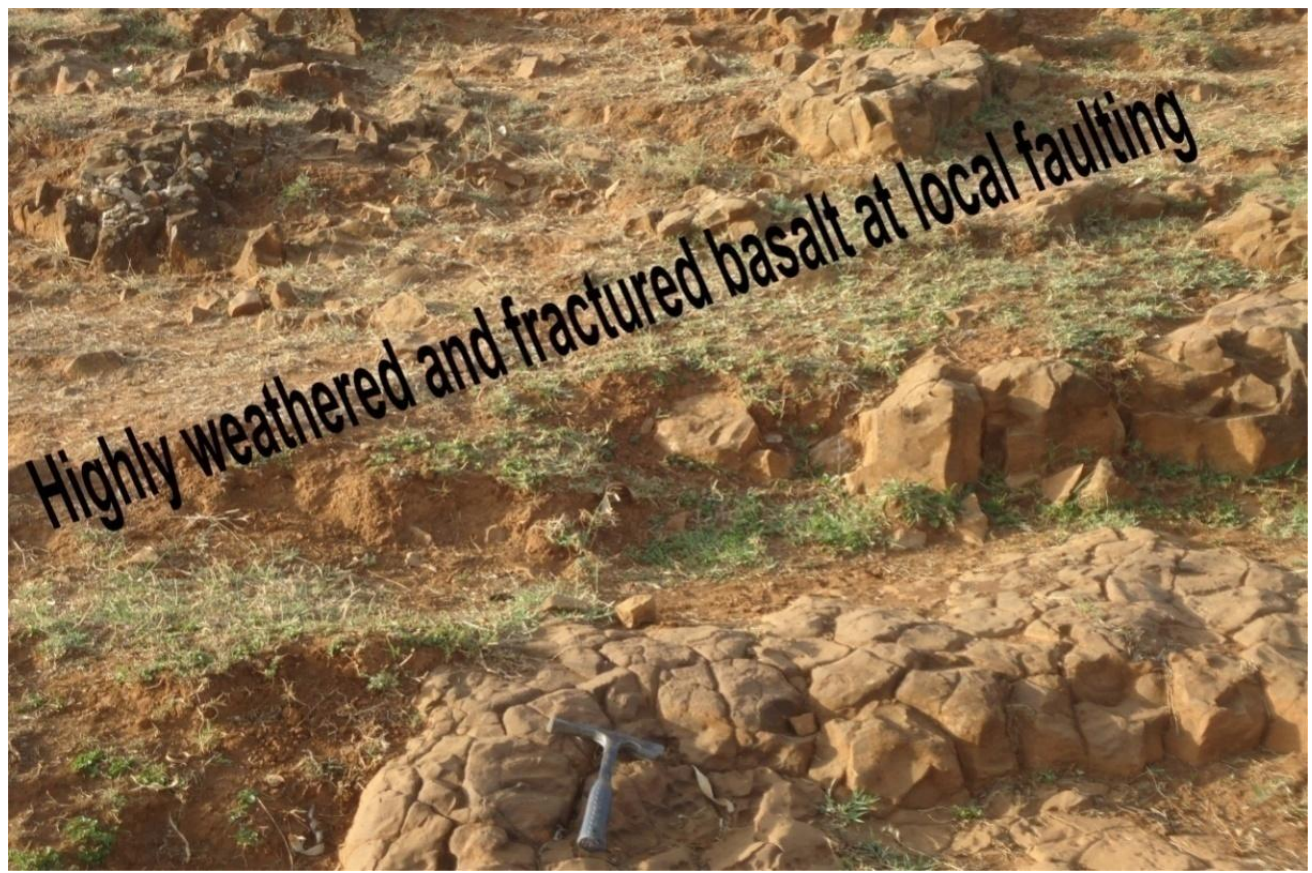

Figure 13: Highly weathered and fractured basalt at local faulting of the selected irrigation fields in the study area.

\section{Aquifers in the Selected Irrigation Site}

In the Fincha'a Sugar Estate irrigation fields, aquifers are generally of two kinds: the shallow or free and the compacted ones. Their conditions show all of the specific characteristics: their total quantity, spread, hydraulic status, potential and groundwater quality. The shallow aquifers in the Fincha'a Sugar Estate irrigation fields varies between 1.59 and 2.49 $\mathrm{m}$ depth and the compact(deep) ones varies between 10.4 and $19.98 \mathrm{~m}$. The shallow aquifers basically consist of wet top and clay soil and the compacted aquifers consist of saturated sand stone and sandy soil.

\section{Geoelectrical Resistivity Measurement}

The field data were interpreted and processed qualitatively and quantitatively by using partial curve matching techniques and computer to obtain the resistivity values of different subsurface layers and their corresponding thickness (Table 1). From the interpretation of VES curves, 6 to 12 subsurface layer where identified within the study area. The curves are prominently of different type indicating the presence of six to twelve layers and sub-surface layers (Figure 8).

Locations VES 1, VES 2, VES 3 and VES 4 can be explained by $\left(\rho_{\mathrm{a}} 6>\rho_{\mathrm{a} 2}>\rho_{\mathrm{a} 4}>\rho_{\mathrm{a} 1}>\rho_{\mathrm{a} 5}>\rho_{\mathrm{a}} 3\right)$, $\left(\rho_{a 9}>\rho_{a 4}>\rho_{a 2}>\rho_{a 8}>\rho_{a 5}>\rho_{a 1} \rho_{a 3}>\rho_{a 6}\right),\left(\rho_{a 4}>\rho_{a 5}>\right.$ $\left.\rho_{\mathrm{a} 6}>\rho_{\mathrm{a} 7}>\rho_{\mathrm{a} 3}>\rho_{\mathrm{a} 1} \rho_{\mathrm{a} 2}\right)$ and $\left(\rho_{\mathrm{a} 12}>\rho_{\mathrm{a} 9}>\rho_{\mathrm{a} 8}>\rho_{\mathrm{a} 10}>\right.$ $\left.\rho_{a 7}>\rho_{a 4}>\rho_{a 5}>\rho_{a 2}>\rho_{a 11}>\rho_{a 6}>\rho_{a 1}>\rho_{a 3}\right)$ six, nine, seven and twelve layer models respectively (Figure 8).

VES1: The resistivity of the first layer (top soil) was $29.3 \Omega-\mathrm{m}$ and a thickness was $0.37 \mathrm{~m}$. In the second layer, hard and compact sand was inferred with the high resistivity value of $237 \Omega-m$ and thickness $0.254 \mathrm{~m}$ and can be mapped relatively as fresh bed rock of basalt and dry and fresh top soil which are not so affected by fractures and joints. The Third layer has resistivity of $3.76 \Omega-m$ and a thickness $0.959 \mathrm{~m}$. This layer acts as the shallow aquifer in these places because this layer consists of fracture or weathered zone which constitutes an aquifer of very good quality of groundwater resulted from the in situ weathering of the basalt rocks interpreted as zone of wet aquifer soil, clay soil, and weathered soil accumulates as a result shallow ground table was identified at depth of $1.5 \mathrm{~m}$. The basement had resistivity and thickness of $121 \mathrm{ohm}-\mathrm{m}$ and 0.52 respectively. The basement resistivity data indicates the rock type is hard and massive. The fiftieth layer was identified as highly weathered wet clay soil and fractured bed rock in which the discontinuities were filled with water had resistivity of $20.6 \Omega-\mathrm{m}$ and a thickness $0.95 \mathrm{~m}$. The resistivity and thickness of the last (six) layer were $355 \Omega-\mathrm{m}$ and a $79.3 \mathrm{~m}$ respectively which might considered as basement rock of driest zone. 
Table 1: Summary of VES data interpretations with positions and Lithology.

\begin{tabular}{|c|c|c|c|c|}
\hline layer & $\rho a(\Omega m)$ & $T(m)$ & $\mathrm{D}(\mathrm{m})$ & Inferred lithology \\
\hline \multicolumn{5}{|l|}{ VES 1} \\
\hline 1 & 29.3 & 0.37 & 0.37 & wet top soil, \\
\hline 2 & 237 & 0.25 & 0.62 & dry and fresh topsoil \\
\hline 3 & 3.76 & 0.95 & 1.59 & Wet, aquifer soil ,clay soil, weathered soil \\
\hline 4 & 121 & 0.52 & 2.11 & sandy soil and basement hard rock \\
\hline 5 & 20.6 & 17.4 & 19.98 & Wet ,clay soil, weathered soil \\
\hline 6 & 355 & 79.3 & Inf. & \\
\hline \multicolumn{5}{|l|}{ VES 2} \\
\hline 1 & 33.3 & 0.75 & 0.75 & wet and weathered topsoil, \\
\hline 2 & 189 & 0.27 & 1.02 & Dry soil and ,fresh sandstone \\
\hline 3 & 5.42 & 1.04 & 2.06 & Wet, aquifer soil and clay soil \\
\hline 4 & 208 & 0.71 & 2.77 & hard sandstone \\
\hline 5 & 36.3 & 1.19 & 3.96 & Wet sandy soil \\
\hline 6 & 5.08 & 3.52 & 7.47 & Wet sandy soil \\
\hline 7 & 14.9 & 2.93 & 10.4 & Wet sandy soil \\
\hline 8 & 128 & 4.54 & 15 & Dry massive sand stone \\
\hline 9 & 404 & 5.74 & 20.7 & Hard basement rocks \\
\hline \multicolumn{5}{|l|}{ VES 3} \\
\hline 1 & 265 & 0.92 & 0.926 & dry and topsoil \\
\hline 2 & 49.3 & 1.52 & 2.45 & wet top soil \\
\hline 3 & 1279 & 0.73 & 3.18 & Hard and massive basement rocks \\
\hline 4 & 91231 & 14.8 & 18 & Hard ,not fractured massive basement rocks \\
\hline 5 & 58998 & 33.8 & 51.9 & Hard ,not fractured massive basement rocks \\
\hline 6 & 47229 & 97.7 & 150 & Hard ,not fractured massive basement rocks \\
\hline 7 & 43503 & Inf. & Inf. & Hard ,not fractured massive basement rocks \\
\hline \multicolumn{5}{|r|}{ 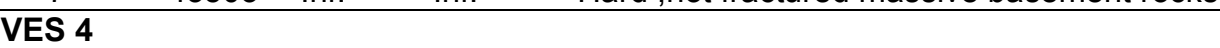 } \\
\hline 1 & 54.7 & 0.75 & 0.75 & wet top soil and weathered topsoil \\
\hline 2 & 145 & 0.41 & 1.17 & dry and topsoil, \\
\hline 3 & 29.4 & 1.33 & 2.49 & Wet Laterite soil \\
\hline 4 & 218 & 0.25 & 2.75 & Dry and massive sand stone \\
\hline 5 & 150 & 2.87 & 5.62 & Dry sandy soil \\
\hline 6 & 64.7 & 5.95 & 11.6 & Wet sand stone \\
\hline 7 & 334 & 0.54 & 12.1 & Dry and massive basement rocks \\
\hline 8 & 907 & 1.49 & 13.6 & Dry and massive basement rocks \\
\hline 9 & 17082 & 14.5 & 28.1 & Dry and massive basement rocks \\
\hline 10 & 707 & 16.9 & 45 & Dry and massive basement rocks \\
\hline 11 & 101 & 29.4 & 74.5 & Fractured volcanic rocks \\
\hline 12 & 3348 & Inf. & Inf. & Dry and massive basement rocks \\
\hline
\end{tabular}

Table 2: Qualitative analysis of curve types where $\rho$ represents resistivity of the layer.

\begin{tabular}{lllc}
\hline VES & $\begin{array}{l}\text { Curve } \\
\text { type }\end{array}$ & Curve Characteristics & $\begin{array}{c}\text { Number } \\
\text { of layers }\end{array}$ \\
\hline 1 & $\mathrm{KH}$ & $\rho_{\mathrm{a} 1}<\rho_{\mathrm{a} 2}>\rho_{\mathrm{a} 3}<\rho_{\mathrm{a} 4}>\rho_{\mathrm{a} 5}<\rho_{\mathrm{a} 6}$ & 6 \\
2 & $\mathrm{KH}$ & $\rho_{\mathrm{a} 1}<\rho_{\mathrm{a} 2}>\rho_{\mathrm{a} 3}<\rho_{\mathrm{a} 4}>\rho_{\mathrm{a} 5}>\rho_{\mathrm{a} 6}<\rho_{\mathrm{a} 7}<\rho_{\mathrm{a} 8}<\rho_{\mathrm{a} 9}$ & 9 \\
3 & $\mathrm{HAK}$ & $\rho_{\mathrm{a} 1}>\rho_{\mathrm{a} 2}<\rho_{\mathrm{a} 3}<\rho_{\mathrm{a} 4}>\rho_{\mathrm{a} 5}>\rho_{\mathrm{a} 6}>\rho_{\mathrm{a} 7}$ & 7 \\
4 & $\mathrm{KH}$ & $\rho_{\mathrm{a} 1}<\rho_{\mathrm{a} 2}>\rho_{\mathrm{a} 3}<\rho_{\mathrm{a} 4}>\rho_{\mathrm{a} 5}>\rho_{\mathrm{a} 6}<\rho_{\mathrm{a} 7}>\rho_{\mathrm{a} 8}<\rho_{\mathrm{a} 9}>\rho_{\mathrm{a} 10}>\rho_{\mathrm{a} 11}<\rho_{\mathrm{a} 12}$ & 12 \\
\hline
\end{tabular}

VES 2: The resistivity of the first layer (top soil) was $33.3 \Omega-\mathrm{m}$ and a thickness was $0.75 \mathrm{~m}$. In the second layer, dry and fresh top soil was inferred with the high resistivity value of 189 ohm-m and thickness $0.27 \mathrm{~m}$. The Third layer has resistivity of $5.42 \Omega-\mathrm{m}$ and a thickness $1.04 \mathrm{~m}$. This layer acts as the shallow aquifer in these places because this layer consists of fracture or weathered zone which constitutes an aquifer of very good quality of groundwater resulted from the in situ weathering of the basalt rocks interpreted as zone of wet aquifer soil, clay soil, and weathered soil accumulates as a result shallow ground table was identified at depth of $2.06 \mathrm{~m}$. The basement rock had resistivity and 
Getahun Kitila et al.,

thickness of $208 \Omega-\mathrm{m}$ and $0.71 \mathrm{~m}$. The basement resistivity data indicates the rock type is hard and massive sand stone. The fifth, the six and the seventh layer with resistivity of $36.35,5.08$ and 14.9 $\Omega$-m respectively was interpreted as wet sandy soil which were filled with water, this might be attributed to basalt and trachitic rocks of the aquifer bearing zone.

VES3: The resistivity of the first layer (dry top soil) was $265 \Omega-\mathrm{m}$ and a thickness $0.92 \mathrm{~m}$. In the second layer, wet top soil of the resistivity value of $49.3 \Omega-\mathrm{m}$ and thickness $1.52 \mathrm{~m}$ and affected by fractures and joints identified and ground water table depth was identified at $3.18 \mathrm{~m}$. The Third, fourth, fivith, six and seventh layer had resistivity of 1279, 91231, 58998, 47229 and $43503 \Omega-m$ and a thickness $0.73,14.8,33.8$ and $97,7 \mathrm{~m}$ were represented as hard, not fractured and massive basement rocks.

VES 4: The resistivity of the first layer (top soil) was $54.7 \Omega-\mathrm{m}$ and a thickness was $0.75 \mathrm{~m}$. In the second layer, dry and fresh top soil was inferred with the high resistivity value of $145 \Omega-\mathrm{m}$ and thickness $0.27 \mathrm{~m}$. The Third layer has resistivity of
Sci. Technol. Arts Res. J., July-Sep 2013, 2(3): 114-125

$29.4 \Omega-\mathrm{m}$ and a thickness $1.33 \mathrm{~m}$. This layer acts as the shallow aquifer in these places because this layer consists of fracture or weathered zone which constitutes an aquifer of very good quality of groundwater resulted from the in situ weathering of the basalt rocks interpreted as zone of wet aquifer soil, clay soil, and weathered soil accumulates as a result shallow ground table was identified at depth of $2.5 \mathrm{~m}$. The basement rock had resistivity and thickness of $218 \Omega-\mathrm{m}$ and $2.75 \mathrm{~m}$ respectively. The basement resistivity data indicates the rock type is hard and massive dry sand stone. The fifth layer with resistivity of $150 \Omega-m$ and thickness $2.87 \mathrm{~m}$ was interpreted as dry sandy soil the six with resistivity of $64.7 \Omega-\mathrm{m}$ and thickness $5.95 \mathrm{~m}$ represented, wet sand stone was filled with water, this might be attributed to basalt and trachitic rocks of the aquifer bearing zone. The dry massive basement rock of resistivity and thickness of $334,907,179082$, and $707 \Omega-\mathrm{m}$ and $0.548,1.49,14.5$ and $16.9 \mathrm{~m}$ was identified at seventh, eighth, ninth and tenth layers respectively. The eleventh layer of resistivity and thickness $101 \Omega-m$ and $29.4 \mathrm{~m}$ showed fractured volcanic rock. The twelve layer of resistivity and thickness $3348 \Omega-m$ and very large represented dry and massive basement rocks.

Table 3: Resistivity value for water and rock. Source (Ibrahim, 2006).

\begin{tabular}{cll}
\hline $\begin{array}{c}\text { Resistivity } \\
\text { (ohm-m) }\end{array}$ & \multicolumn{1}{c}{ Sediment Rock } & \multicolumn{1}{c}{ Interpretation } \\
\hline $0.5-2.0$ & Very porous sand & Seawater, very saline water TDS $=20,000 \mathrm{mg} \mathrm{L}^{-1}$ \\
$2.0-4.5$ & Porous sand, or saturated clay & saline water TDS $=10,000 \mathrm{mg} \mathrm{L}^{-1}$ \\
$4.5-10$ & Sandy saturated or sandy clay & Salty Brackish water, TDS $=10,000 \mathrm{mg} \mathrm{L}^{-1}$ \\
$10.0-15$ & Sandy clay, sandy gravel & Brackish water, TDS $=5000-1500 \mathrm{mg} / \mathrm{l}$ \\
$15.0-30$ & Sand, gravel, some clay & Poor quality fresh groundwater, TDS $=1500-700 \mathrm{mg} \mathrm{L}^{-1}$ \\
$30.0-70$ & Sand, gravel, minor clay & Intimidate quality fresh groundwater, TDS $=1500-700 \mathrm{mg} \mathrm{L}^{-1}$ \\
$70.0-100$ & Sand, gravel, no clay & Good quality fresh groundwater, TDS small \\
$>100$ & Coarse Sand, gravel, no clay & Very good quality fresh groundwater, TDS very small \\
\hline
\end{tabular}

\section{DISCUSSION}

The detected lithological layer of top soil, clay, laterite, sandy clay, sandy soil, loose sand and clean sand were all aquifer or water bearing layers. Therefore, the study area was rich in groundwater and this might be the cause for the groundwater table rise in the selected irrigated fields of the study area. Low moisture contents were found by the increase in depth. The reason for the existence of fresh groundwater in the sub-soil was that the strata contained a mixture of dry sand and Adigrat sand stone (Figure 10).

The shallow aquifers within the first, second, third and fourth layers were at depth of about 1.59, 2.06, 2.45 and $2.49 \mathrm{~m}$ with resistivity value of $3.76,5.42$, 49.3 and $29.4 \Omega-m$ respectively indicated the irrigation fields where all of VES were under sever waterlogging condition and it was identified the severity was maximum for the first two VES (Figure 9). This in consistent with the value obtained with GIS environment from pizometer data analysis for the same fields (which the second paper of this work done for comparison). The second aquifer in the fivith layer at a depth of $19.8 \mathrm{~m}$ and resistivity value of $20 \mathrm{ohm}-\mathrm{m}$ is not a confined layer. It was clearly identified from this study that the plateau basalts are the major causes of waterlogging in the selected irrigation fields of the study area (Figure 10 ) in addition to in addition to poor irrigation water management, soil type, slope and drainage.

The study revealed that the quality of groundwater increased with increase in resistivity but the existence of water decreased with increased value of resistivity and the variation of resistivity 
Getahun Kitila et alo,

values of water locations showed that the variation of water flow was affected by the medium type. The results showed that there were significant different resistivity values of sounding points (Table 1) this is good evident that soil compaction affects apparent resistivity of rock materials. The study, indicated that the water quality was good at VES 3 when compared to VES 1, VES2 and VES4 (Table 3) as it was more compacted irrigated field than others . This also showed that the geological structure affected the quality of groundwater in the irrigated fields (Figure 10). Theoretically, every kind of rock transmits electric current and has its own resistivity but the rock of the same kind may not necessarily have the resistance. Conversely, the same resistivity value may point to a different kind of rock. Other factors such as lithological composition, rock condition, mineral composition, and liquid content influence the values of electrical currents and material resistivity and so do other external factors. Rocks resulted from loose sedimentation show a low resistivity value when compared to compact rocks, dry rocks have a high resistivity and Wet rocks contain in a lot of water and have low resistivity value. Mineral content in the surrounding area of a pack of rock, wires thickness, electrode rods, and topographic condition are among the factors that influence the resistivity of rock. The most part of the study area consists of good quality of groundwater because the study area is dominated by the $\mathrm{H}$ type curve (Table 2) this result is in consistent with that of (Selvam and Sivasubramanian, 2012). The above data was compared to the other finding values (Table 3 ) that indicate that shallow water was found in the depth of approximately $1.5 \mathrm{~m}$ with the resistivity values of $3.76 \Omega \mathrm{m}$ (VES1), $2.06 \mathrm{~m}$ in depth and with the resistivity value of $5.42 \Omega \mathrm{m}$ (VES 2 ), $3.18 \mathrm{~m}$ with the resistivity value of $49.3 \Omega \mathrm{m}$ (VES 3 ) and $2.49 \mathrm{~m}$ with the resistivity value of $29.4 \Omega \mathrm{m}$ (VES4) respectively. In addition to poor farm water management, soil type, slope and drainage, the nature of the basement was identified as the cause for the waterlogging problem of the irrigated fields of the study area. The observed irrigated fields were under critical to sever conditions of waterlogging. Thus storage of considerable deep drainage in the irrigation fields in regolith to keep the waterlogged irrigated fields dry by native vegetation, preventing it from contributing to recharge is one of the solutions to minimize the problem. It is not possible to determine from resistivity imaging whether deeper layers (e.g. $>15 \mathrm{~m}$ ) are also wet because they are resistive in the unsaturated zone and below the water table, due to low salinity of the groundwater. Deeper coring is required to determine the moisture status and confirm the salinity of these deeper materials.
Sci. Technol. Arts Res. J., July-Sep 2013, 2(3): 114-125

\section{CONCLUSIONS}

Present work has shown that in a hard rock environment, Vertical Electrical Sounding (VES) has proved to be very reliable for underground water studies and therefore the method can excellently be used for shallow and deep underground water geophysical Resistivity investigation. The most part of the study area consists of good quality of groundwater because the study area is dominated by the $\mathrm{H}$ type curve. The top layer is the black cotton soil and it is followed by a weathered zone which is underlain by basement rock.

Fractured basalt and nature of the basement in the study area was identified as major cause for the study site to have maximum average relative humidity, unique under Ethiopian condition and for most of irrigated Vertisols to be waterlogged within 10-25 years of irrigation in addition to other natural and human induced factors

The observed irrigated fields were under critical to sever conditions of waterlogging. Thus considerable deep drainage from irrigation has been stored in regolith previously kept dry by native vegetation, preventing it from contributing to recharge. It is not possible to determine from resistivity imaging whether deeper layers (e.g. $>15 \mathrm{~m}$ ) are also wet because they are resistive in the unsaturated zone and below the water Table, due to low salinity of the groundwater. Deeper coring is required to determine the moisture status and confirm the salinity of these deeper materials.

\section{ACKNOWLEDGMENT}

The authors are grateful for the financial grant of Wollega University Research Directorate. We are also acknowledging all people at Fincha'a Sugar Estate who contributed their Knowledge and skill in support, advice and material assistance during the whole study time. The assistance of the staff and GIS expertise of Earth science department of Wollega University especially Mr. Gizachew Kabite and Mr. Muleta Ebsa for their assistance in GIS work are gratefully acknowledged for their unreserved assistance.

\section{REFERENCES}

Amadi, A., Nwawulu, C. and Unuevhol, C. (2011). Evaluation of the groundwater potential in Pompo village, Gidan Kwano, Minna using vertical electrical resistivity soundingBritish Journal of Applied Science \& Technology 1: 53-66.

Girma, A. and Ambachew, D (2005). Review of sugar cane research in Ethiopia: I. Soil irrigation and mechanization (1964-1998), RTSD, ESISCSh.Co., Wonji. 


\section{Getahun Kitila et al.,}

Ahmed A. A. (2007). GIS and remote sensing integrated environmental impact assessment of irrigation project in Fincha'a Valley area, Ethiopia. Catchment and Lake Research.

Bayissa, C. (2007). Assessment of Malaria as a Public Health Problem in Fincha'a Sugar Factory Based on Clinical Records and Parasitological Surveys. MSc Thesis. Addis Ababa University, Ethiopia.

Bobachev, A. and Modin, N. (2000). IPI2Win Software, Geoscan-M, Ltd, Moscow, Russia.

El-Qady, G. (2006). Exploration of a geothermal reservoir using geoelectrical resistivity Inversion: case study at Hammam Mousa, Sinai, Egypt. Journal of Geophysics and Engineering 3: 114-21.

Fetter, C. (1994). Applied Hydrogeology, third ed. Prentice-Hall, Inc., New Jersey, p. 600.

Gunawardena, A., McGarry, D., Gardner, E. and Stirzaker, R. (2008). Managing Deep Drainage For Improved WUE: Solute Monitoring and Ground Water Response in the Irrigated Landscape. In "Proceedings of the $14^{\text {th }}$ Australian Cotton Conference." Broad beach, Australia.

Ibrahim, E. (2008). Identification of Groundwater Spreading by Using Geoelectrical Resistivity. International Journal of Science Engineering and Technology 1( 3): 93-97

Ismailmohamaden, M.I., (2005). Electric resistivity investigation at Nuweiba Harbour Gulf of Aqaba, South Sinal, Egypt. Egypt. Journal of Aquatic Research 31: 57-68.

Jenny, F., Mark, S. and Anna G. (2010). Resistivity imaging across native Vegetation and Irrigated Vertisols of the Condamine catchment a snapshot of changing regolith water storage. World Congress of Soil Science, Soil Solutions for a Changing World. Brisbane, Australia.

Khalil, M.A. and. Monterio, F.A. (2009). Influence of degree of saturation in the electric resistivityhydraulic conductivity relationship. Survey Geophysics., pp. 123. $10.1007 / \mathrm{s} 10712-009-9072-4$.

MOA (Ministry of Agriculture). (1998). Agro- ecological zones of Ethiopia, Natural Resources Management and Regulatory Department, Addis Ababa, Ethiopia.

Murphy, G. (2008). Management of Groundwater Condamine River and tributary alluvium: Information paper for groundwater licensees and users (Central Condamine River Alluvium). (Department of Natural Resources and Water: Brisbane).
Sci. Technol. Arts Res. J., July-Sep 2013, 2(3): 114-125

Olowofela, J.A., Jolaosho, V.O. and. Badmus, B.S (2005). Measuring the electrical resistivity of the earth using a fabricated resistivity meter. European Journal of Physics 26: 501-515.

Omosuyi, G.O.,Adeyemo,A.and Adegoke, A.O. (2007). Investigation of groundwater prospec using electromagnetic and geoelectricsoundingat afunbiowo, near Akure, Southwestern Nigeria. Pacific Journal of Science and Technology 8: 172-182.

Oseji, J.O., Atakpo, E.A and Okolie, E.C. (2005). Geoelectric investigation of the aquifer characteristics and groundwater potential in Kwale, Delta state, Nigeria. Journal of Applied Sciences and Environmental Management 9: 157-160.

Patra, H. and Nath, S. (1999). Schlumberger geoelectric sounding in ground water: Principles, Interpretation and applications. Oxford \& IBH Publishing Company Pvt. Ltd., New Delhi, p. 153.

Selvam, S. and Sivasubramanian, P. (2012). Groundwater potential zone identification using Geoelectrical survey: A case study from Medak district, Andhra Pradesh, India. International Journal of geometrics and Geosciences 3(1): 55-62..

Singh, K.K.,. Singh, A.K., Singh, K.B. and Sinha, A. (2002). 2D resistivity imaging survey for siting watersupply tube well in metamorphic terrains: A case study of CMRI campus, Dhanbad, India. The Leading Edge 25: $1458-1460$.

Todd, D.K., (1980), Groundwater hydrology. John Willey Sons. Inc. New York, pp, 535.

Tahmasbinejad, H. (2009). Geoelectrical investigation of the aquifer characteristics and Groundwater potential in Behbahan Azad university farm, Khuzestan province. Iranian Journal of Applied Animal Science 9: 3691-3698.

Yusuf, S., Joseph, M., Alkali, S. and Kuku, A. (2011). Determination of porous zones using Vertical electrical sounding data from basement rocks of Hussara, Askira UBA, North-eastern Nigeria. Ozean Journal of Applied Science 4: 183-9.

Worku, B. (1995). Agro ecological Conditions and Back Ground Information on Fincha'a Sugar Factory, Fincha'a research station, Ethiopia. MSc Thesis. Alemaya University, Ethiopia. 